\title{
АКТУАЛЬНІ ПРОБЛЕМИ ОПАНУВАННЯ ПРАКТИЧНИХ НАВИЧОК НА КАФЕДРІ ЗАГАЛЬНОЇ ХІРУРГІЇ НА ЗАСАДАХ БОЛОНСЬКОЇ ДЕКЛАРАЦІї
}

\author{
О. Ю. Іоффе, В. С. Кульбака, В. М. Меллін, М. М. Стець, О. П. Стеценко \\ Національний медичний університет імені О. О. Богомольия
}

\section{TOPICAL PROBLEMS IN STUDENTS' MASTERING OF PRACTICAL SKILLS IN GENERAL SURGERY ACCORDING TO THE BOLOGNA DECLARATION}

\author{
O. Yu. Ioffe, V. S. Kulbaka, V. M. Mellin, M. M. Stets, O. P. Stetsenko \\ National Medical University by O. O. Bohomolets
}

\begin{abstract}
Вирішення проблем освоєння практичних навичок полягає у створенні належної мотивації у викладачів і студентів, сучасному матеріально-технічному оснащенні клінік, зменшенні кількості студентів в академічних групах, збереженні кращих традицій медичної освіти України.
\end{abstract}

There are a few terms for successful solution of the students' problems to master practical skills. They are: due motivation of teachers and students; modern material, technical and technological support; downsizing of students' academic groups; preservation of the best traditions of medical university education of Ukraine.

Вступ. Досвід викладання загальної хірургії на засадах Болонської декларації співробітники набувають в умовах проведення реформування медичної галузі. Останнє передбачає підвищення якості теоретичних знань $і$ їх виживання, оволодіння базовими практичними навичками і уміннями, необхідними в діяльності сімейного лікаря [1,2].

Не викликає сумнівів, що для досягнення максимального ефекту від вивчення загальної хірургії основи всіх предметів хірургічного профілю - студенти повинні засвоювати основи теоретичних знань, активно їх використовувати для оволодіння практичними навичками, постійно знайомитися з новітніми медичними технологіями та методиками $[3,4]$.

Безперечними умовами поліпшення додипломної теоретичної і практичної підготовки є створення позитивної мотивації у студентів, щодо вивчення предмета, готовність майбутніх лікарів до самостійної навчально-пізнавальної діяльності, наявність достатньої клінічної і матеріальної бази, усвідомлення, що лікарю необхідно навчатися все життя $[5,6]$.

Основна частина. Мета роботи полягає у визначенні актуальних питань опанування студентами практичних навичок і вдосконаленні методичних підходів в додипломній практичній підготовці лікаря ( ) О. Ю. Іоффе, В. С. Кульбака, В. М. Меллін та ін. широкого профілю в умовах кредитно-модульної організації навчання.

Основу роботи склав аналіз результатів викладання догляду за хірургічними хворими, загальної хірургії та сестринської практики студентам першого та четвертого медичних факультетів на кафедрі загальної хірургії № 2 Національного медичного університету (НМУ) в 2006 - 2011 н. р. Предметом дослідження були вивчення ступеня інтеграції цих предметів з базовими дисциплінами (анатомією людини, нормальною фізіологією, біохімією) та використання знань цих предметів під час оволодіння практичними навичками на поточних заняттях.

Під час поточного практичного заняття і підсумкового модульного контролю (ПМК) порівнювали якість і стійкість освоєння практичних навичок. Для вивчення мотивації студентів до оволодіння практичними навичками 3 догляду за хворими і загальної хірургії провели анонімне анкетування 450 студентів медичного факультету № 1 і 360 - смедичного факультету № 4 з подальшим аналізом анкет.

Програма оволодіння практичними навичками органічно та методично поєднана з освоєнням теоретичного матеріалу. В створених викладачами кафедри методичних рекомендаціях для викладачів та вказівках для студентів до кожного заняття містить- 
ся грунтовно написаний зміст теми, та по 60 тестових питань і 20 ситуаційних задач, а також перелік практичних навичок, якими мають оволодіти студенти на кожному занятті.

На засіданнях кафедри регулярно, двічі на місяць, обговорюються проблеми удосконалення організації навчання за кредитно-модульною системою, в тому числі процес оволодіння практичними навичками. В структурі кожного практичного заняття самостійна робота студентів під керівництвом і $з$ допомогою викладача становить від 40 до 60 \% і базується на засвоєнні тематичного матеріалу змістовного модуля та знаннях, отриманих на фундаментальних кафедрах.

Аналіз тестового контролю знань студентів 3 базових дисциплін, проведений на початку 6-го семестру, показав, що менше п'ятдесяти відсотків охоплених дослідженнями студентів мали за виконання тестових 3 теоретичних предметів четвірки і трійки. Більша ж частина отримала незадовільні оцінки. Результати перевірки базових знань та інші проблемні питання навчання були розглянуті разом із студентами в академічних групах. Такий підхід орієнтує студентів на доцільність і необхідність систематичного відновлення знань з фундаментальних дисциплін.

Практичні навички, які набувають студенти, вивчаючи загальну хірургію, умовно розподілено на три piвні.

Перший-інструментальне обстеження, маніпуляції, процедури, які вимагають попереднього ознайомлення з ними, знання принципу їх дії, алгоритму виконання підготовки хворих до обстеження, вміння підібрати необхідні інструменти для виконання. До них належать: ультразвукове дослідження, фістулографія, комп'ютерна томографія, магнітно-резонансна томографія, доплерографія, методики шарячого катетера, інтубація трахеї, трахеостомія, пункція підключичної вени та ін.

3 практичними навичками першого рівня студенти ознайомлюються протягом семестру, під час вивчення тем: “Особливості інструментальних методів обстеження хірургічних хворих”, “Курація хірургічних хворих", демонстрації хворих викладачами кафедри, засідань наукового гуртка, вечірніх чергувань і обходів, а також самостійно, вивчаючи спеціальну літературу, інформацію з Інтернету, відвідування виставок з охорони здоров' я, підготовки рефератів, які заслуховуються на практичних заняттях в групах. Спостереження лапароскопічних холецистектомій та малоінвазивних операцій, ультразвукових та доплерографічних досліджень розширює кругозір і пізнання сучасних методів діагностики та лікування.
Другий - практичні навички, якими студенти оволодівають, виконуючи їх в доклінічних умовах (в навчальних кімнатах) під час вивчення відповідних тем практичних занять. Виконання навичок цієї категорії продовжується шляхом тренінгу самостійно (вдома чи в гуртожитку), під час ургентних чергувань клініки під керівництвом викладача, самостійних занять в спеціально обладнаній навчальній кімнаті - "практичні навички". До цієї категорії відносяться навички: розчинення антибіотиків, визначення групи крові, проведення тимчасової та постійної зупинки кровотечі (накладання джгута, перев' язка судин, прошивання судин та тканин, накладання транспортних шин, пов'язок, внутрішньом'язові, підшкірні та внутрішньошкірні ін'єкції; венопункція, веносекція, трахеостомія (на макетах), методи дренування плевральної порожнини, підготовка систем для внутрішньовенного вливання розчинів, зовнішній масаж серця та штучне дихання на контролюючих тренажерах тощо. Вищеназвані практичні навички студенти засвоюють на рівні уміння і більшість 3 них на практиці уміють виконувати і в клінічних умовах.

Третій - практичні навички, які студенти набувають в палатах, перев' язочних, маніпуляційних (проведення суб' єктивного та об'єктивного обстеження хворих, визначення груп крові, проведення проб на групову та резус-сумісність, біологічної проби, підготовка систем для внутрішньовенного введення розчинів, зняття швів, замінення пов' язок, взяття мазків для визначення виду мікрофлори і чутливості їі до антибіотиків, визначення наявності алергічних реакцій на антибіотики, новокаїну, виконання підшкірних, внутрішньом'язових ін'єкцій, проведення місцевої інфільтраційної анестезії методом повзучого інфільтрату та ін.).

Студенти-одногрупники, які отримали середню медичну освіту і мають досвід роботи за фахом, допомагають своїм товаришам набути відповідних умінь і навичок в клініці та під час самостійної підготовки.

Велику увагу приділяємо клінічним розборам історій хвороби стаціонарних хворих, вважаючи, що це $\epsilon$ ефективною формою навчання студентів. Під час розбору клінічного випадку захворювання відбувається спілкування майбутніх лікарів 3 хворим і 3 викладачем, при якому проявляється активна пізнавальна діяльність.

Перевірка базових знань (загального аналізу крові, показників гомеостазу та ін.) в порівнянні з отриманими лабораторними даними в присутності хворого викликає мотивацію до відновлення знань з фундаментальних дисциплін, стимулює учасників навчаль- 
ного процесу до освоєння практичних навичок.

Підвищенню мотивації для оволодіння практичними навичками у студентів молодших курсів сприяють викладачі кафедри, надаючи можливість бажаючим працювати під час ургентних чергувань в приймальному відділенні, операційних, гіпсувальній, маніпуляційних, на медсестринських постах.

Аналіз якості виконання і “виживання” умінь з практичних навичок під час ПМК показав, що тільки половина студентів першого медичного і 40 \% четвертого медичного факультетів змогли без зауважень i підказок викладача виконати практичне завдання. В зв'язку з отриманими результатами було прийняте рішення включити в перелік до всіх ПМК навичок невідкладної допомоги, проводити консультативне заняття перед ПМК, яке направлено в основному на відновлення та тренінг з практичних навичок.

Анкетне опитування студентів виявило різний рівень мотивації до вивчення загальної хірургії. Студенти другого курсу медичних факультетів № 1 та № 4 добре мотивовані до навчання та оволодіння практичними навичками. Студенти третього курсу першого медичного факультету і четвертого медичного факультету мають спад мотивації до навчання. В анкетах вони відмічали низьку майбутню заробітну плату лікаря, неможливість працювати за вузькою спеціальністю після закінчення ВНЗ, що негативно впливає на бажання вчитися. Слабка мотивація студентів до навчання проявляється в неякісній самостійній підготовці до практичних занять, неуважністю під час доклінічного відпрацювання практичних навичок, нетривалій стійкості знань та практичних навичок, в небажанні глибоко вивчати предмет.

Відпрацьовуючи під керівництвом викладача практичні навички, студенти мають у своєму розпорядженні все необхідне: комплекти хірургічних інструментів, підібраних для даної маніпуляції (веносекції, трахеостомії, плевральної пункції, скелетного витяжіння, новокаїнових блокад тощо); короткі методичні вказівки, таблиці, малюнки, слайди і схеми виконання навичок, в яких зазначені показання, протипоказання до проведення тих чи інших маніпуляцій, метод виконання знеболення, оснащення, можливі ускладнення та засоби їх усунення.
Успішне оволодіння практичними навичками, здатність студентів виконати їх через деякий час можлива тільки при неодноразовому відпрацюванні маніпуляції протягом навчання у вузі.

Багаторічний досвід викладання загальної хірургії та наслідування добрих традицій наших попередників свідчить про те, що всі без винятку практичні заняття на другому і третьому курсах, включаючи заліки по модулях, є часом і місцем, де по краплинах карбується особистість майбутнього практичного лікаря.

Навчити практичним навичкам на рівні уміння усіх студентів на основі досвіду викладача і його рекомендацій за правилом “виконуй, як я”, що було головним принципом традиційної системи медичної освіти, досить важко. Треба зважати на чисельні групи студентів по 10-11 осіб в кожній, що перебувають в клініках одночасно. Крім того, за короткий період виробничої практики в ранні або пізні години навчання студентів, значна кількість маніпуляцій може не виконуватися в клініці, що обмежує можливість оптимальної додипломної підготовки лікаря сімейної медицини. Система вищої медичної освіти України в умовах реформи згідно з Болонською декларацією втратила одну із кращих традицій - літню виробничу практику на третьому курсі. Сучасні студенти отримали великі привілеї - відпочивати 2 місяці влітку, безнадійно мріючи і сподіваючись на свою майбутню конкурентну спроможність у Свропейському освітньому і професійному просторі. Ситуація зрозуміла усім організаторам реформи вищої медичної освіти. Прийняти відповідне рішення щодо відновлення виробничої практики в літній період нелегко, але доцільно.

Висновки: 1. Підвищення стійкості знань, практичних навичок та умінь визначається мотивацією студентів до вивчення предмета і практичної діяльності, потребує багаторазового повторення практичних навичок під час навчання у ВНЗ.

2. Якісне оволодіння студентами практичними навичками інтенсифікує засвоєння матеріалу на рівні усвідомлення і розуміння, складає передумови для правильного цілеспрямованого використання їх у лікувальній практиці. 


\section{ВДОСКОНАЛЕННЯ ВИЩОЇ МЕДИЧНОЇ ОСВІТИ}

\section{Література}

1. Викладання хірургії в умовах кредитно-модульної системи / І. Є. Бородаєв, І. В. Шарапов, О. Б. Зубков [та ін.] // Медична освіта. -2011. - № 3.-- С. 53-54.

2. Думанський Ю. В. Освоєння студентами практичних навичок при кредитно-модульній організації навчального процесу : проблеми та пошук шляхів іiї вирішення / Ю. В. Думанський, О. М. Талалаєнко, М. Б. Первак // Медична освіта. - 2011.-№ 3. - С. 79-81.

3. Особливості викладання дисципліни “Хірургія” за кредитно-модульною системою / Л. Я. Ковальчук, О. Л. Ковальчук, А. Д. Беденюк [та ін.] // Медична освіта. - 2011. №4. - C. 5 .

4. Досвід використання мультимедійних технологій у навчальному процесі на клінічних кафедрах Івано-Франківського національного медичного університету / І. О. Костіцька, О. І. Бабенко, О. М. Дідушко [та ін.] // Медична освіта. - 2010. - № 1. - С. 58-60.

5. Півторак К. В. Формування особистості та мотивації до навчання у студентів медичного університету / К. В. Півторак, І. В. Феджага // Медична освіта. - 2011. - № 4. - C. 28-31.

6. Опанування студентами практичних навичок як складова частина покращення якості навчального процесу на кафедрі нейрохірургії і неврології Одеського державного медичного університету / А. С. Сон, В. В. Добровольський, Ю. І. Горанський [та ін.] // Медична освіта. -2011.-№ 1.-С. 32-34. 